\title{
Magnolol suppressed cell migration and invasion and induced cell apoptosis via inhibition of the NF-kB signaling pathway by upregulating microRNA-129 in multiple myeloma
}

\author{
Weimei JIN*, Xiaoli WANG*, Yuxiao ZENG, Yifen LAN, Xiaoqiu WANG* \\ Hematology Department, Lishui People's Hospital, The Sixth Affiliated Hospital of Wenzhou Medical University, The First Affiliated Hospital of \\ Lishui College, Lishui, Zhejiang, China
}

*Correspondence: wangxiaoqiu_wxq1@163.com

${ }^{*}$ Contributed equally to this work.

Received September 23, 2020 / Accepted November 30, 2020

\begin{abstract}
Multiple myeloma (MM) is incurable cancer in the blood system. Magnolol is an effective component against various cancers. This study tried to investigate the effect and mechanism of magnolol on MM via regulating miR-129. Human normal plasma cells (nPCs) and MM cells U266 and LP1 were used in this study, accompanied by treatment of magnolol. The miR-129 inhibitor was transfected into U266 and LP1 cells during experiments. Cell viability was detected by Cell Counting Kit-8 assay. Cell migration and invasion were tested by wound healing assay and Transwell assay. And AnnexinV-FITC/PI assay was utilized to assess cell apoptosis. miR-129, miR-1271-5p, miR-342-3p, and miR-124-3p expressions were detected by quantitative reverse transcription-polymerase chain reaction (qRT-PCR), and western blot was adopted to evaluate Cyclin D1, matrix metalloprotein (MMP)-7, MMP-9, phosphorylation (p)-IкBa, p-p65, and p65 protein levels. In U266 and LP1 cells, with magnolol concentration increasing, cell viability, migration, and invasion rates, Cyclin D1, MMP-7, and MMP-9 expressions decreased, while cell apoptosis rose. And magnolol increased the miR-129 expression in MM cells. Besides, miR-129 inhibitor antagonized the above-mentioned effect of magnolol and partly offset the magnololinduced decrease of p-IкBa and p-p65 expression, as well as the ratio of p-p65 to p65 in U266 and LP1 cells. Magnolol suppressed cell migration and invasion and induced cell apoptosis via inhibiting NF- $\mathrm{kB}$ pathway activation, by upregulating miR-129 in MM.
\end{abstract}

Key words: magnolol, multiple myeloma, miR-129, apoptosis, NF- $\mathrm{B}$

Multiple myeloma (MM) is a hematological malignancy characterized by abnormal proliferation of monoclonal plasma cells in the bone marrow [1], the clinical manifestation of which includes anemia, renal failure, hypercalcemia, and bone lesions (CRAB) [2]. The pathogenesis of MM is associated with multiple mechanisms of molecules and cells such as genetic changes and the unbalance of stromal and plasma cells in the bone marrow microenvironment $[3,4]$. In spite of medical progress in immunotherapy, chemotherapy, radiotherapy, and hematopoietic autologous stem cell transplant, MM remains an incurable disease with a 10 -year survival rate of no more than $30 \%[5,6]$, partly due to the lack of precision therapies targeting specific oncogene involved in the pathogenesis [7]. In recent years, researches on MM have revealed the functions of several molecules and compounds like long noncoding RNA XLOC_013703, PCAT-1, and resveratrol, offering limited help to the treatment of $\mathrm{MM}$ [8-10]. Besides, some agents such as thalidomide, lenalidomide, and bortezomib have the potential of extending the overall survival of MM patients, however, MM remains an incurable disease, and eventually almost all patients relapse and become resistant to the chemical treatment [11]. Therefore, it is of importance in theory and practice to search for innovative therapeutic targets as well as effective drugs against MM to improve the survival of MM patients.

Traditional Chinese medicines have the advantages of limited adverse effects, significant efficiency, and activetarget diversity [12]. Magnolol is a bioactive component extracted from root and bark of which is used as a traditional Chinese herbal medicine. And it has been reported that magnolol fulfills a function on muscle relaxation, antianxiety, anti-depressant, anti-oxidation, anti-inflammatory, 
and anti-atherosclerosis [13, 14]. Additionally, previous studies showed magnolol promoted cell apoptosis and suppressed cell development to reduce the malignance of various cancers including prostate cancer, osteosarcoma, breast, and colorectal cancer [14-18]. However, few studies elucidated the effect of magnolol on MM and its mechanism of action.

microRNA (miRNA), a group of small non-coding endogenous RNA implicated in regulation after transcription, has been regarded as a crucial point in cell differentiation, multiplication, migration, and carcinogenesis $[19,20]$. As a member of the miRNA family, miR-129 is also related to tumors and has been found dysregulated in cancers. Besides, miR-129 has been proven to play a negative part in the cell development of multiple cancers. For instance, miR-129 inhibits cell proliferation, migration, and invasion in prostate cancer as well as suppresses cell growth and progression in glioma and glioblastoma multiforme [21-23]. What's more, a significant reduction of miR-129 has been observed in MM tissue and overexpression of miR-129 disturbs cell growth and proliferation while induces cell apoptosis in MM [10]. Consequently, from all above, we try to study whether magnolol functions on MM by regulating miR-129.

This paper firstly explored the role of magnolol in MM and then investigated the specific mechanism of magnolol through targeting miR-129 during MM, attempting to provide a possible therapeutic strategy of MM.

\section{Materials and methods}

Cell culture. The MM cell lines U266 and LP1 were obtained from Shanghai Yaji Biological Technology Co., Ltd. (YS302C; YS2346C, Shanghai, China, http://www.yajimall. $\mathrm{com} /$ ) and human normal plasma cells (nPCs) were bought from Fenghui Biotechnology Co., Ltd (Changsha, China). Cells were cultured in RPMI-1640 medium (31800, Beijing Solarbio Science \& Technology Co., Ltd., Beijing, China) supplemented with $10 \%$ fetal bovine serum (FBS; 110118611, Beijing Solarbio Science \& Technology Co., Ltd., China) in an incubator at $37^{\circ} \mathrm{C}$ with $95 \%$ humidity as well as $5 \% \mathrm{CO}_{2}$.

Cell transfection. Cells in the logarithmic phase were trypsinized (T1350, Beijing Solarbio Science \& Technology Co., Ltd., China), seeded at a density of $1 \times 10^{5}$ cells/well in a 24 -well plate, and cultured until $70-90 \%$ confluence. miR-129 inhibitor (B03001, Shanghai GenePharma Co., Ltd., Shanghai, China) and inhibitor control (B04003, Shanghai GenePharma Co., Ltd., China) were transfected into U266 and LP1 cells using Lipofectamine 3000 (L3000001, Thermo Fisher Scientific, Waltham, MA, USA). Lipofectamine 3000 $(0.75$ and $1.5 \mu \mathrm{l})$ and DNA $(1 \mu \mathrm{g})$ were diluted in Opti-MEM medium $(25 \mu$ l; 31985062 , Thermo Fisher Scientific, USA), respectively. Then $\mathrm{P} 3000$ reagent $(2 \mu \mathrm{l})$ was added into diluted DNA and mixed well. Next, a DNA-reagent mixture was added to dilute Lipofectamine 3000 (1:1) for incuba- tion at room temperature for $10 \mathrm{~min}$. Finally, a DNA-lipid complex $(50 \mu \mathrm{l} /$ well $)$ was added to cells and the plate was incubated for $24 \mathrm{~h}$ at $37^{\circ} \mathrm{C}$.

Cell Counting Kit-8 (CCK-8) assay. Cells in the logarithmic growth were trypsinized and seeded in 96-well plates at $4 \times 10^{3} /$ well, followed by incubation containing $5 \% \mathrm{CO}_{2}$ at $37^{\circ} \mathrm{C}$ for $24 \mathrm{~h}$. Then, the cells were treated with different concentrations of magnolol $(5,10,20,40 \mu \mathrm{M}$; M3445, Sigma-Aldrich, Ontario, Canada) for another 24 or 48 h. Subsequently, $10 \mu \mathrm{l}$ CCK-8 solution (CA1210, Beijing Solarbio Science \& Technology Co., Ltd., China) was added into each well and cells were further incubating for $4 \mathrm{~h}$ at $37^{\circ} \mathrm{C}$. The absorbance was measured at $450 \mathrm{~nm}$ by a microplate reader (SpectraMax iD5, Molecular Devices, Sunnyvale, CA, USA).

Wound healing assay. Cells were seeded at $5 \times 10^{5} /$ well of 6-well plates and cultured until $80-100 \%$ confluence. A pipette tip was used for a straight scratch. Then cells were rinsed 3 times with PBS to remove those detached cells and replaced with serum-free medium for $48 \mathrm{~h}$ at $37^{\circ} \mathrm{C}$. An inverted biological microscope (magnification: 100×; XSP-19C, Shanghai Optical Instrument Co., Ltd., Shanghai, China, https://www.shoif.com/) was used for image capture at 0 and $48 \mathrm{~h}$ and a migrated distance was measured by ImageJ, version 1.48 (National Center for Biotechnology Information, Bethesda, MD, USA). Cell migration rates were performed as the percentage of the scratch area filled by migrating cells at $48 \mathrm{~h}$ post scratch: migration rate $=($ scratch width at $0 \mathrm{~h}-$ scratch width at $48 \mathrm{~h}$ )/scratch width at $0 \mathrm{~h} \times 100 \%$.

Transwell invasion assay. Cells were trypsinized, rinsed with PBS, and resuspended in the serum-free medium at a concentration of $3 \times 10^{5} / \mathrm{ml}$. The cells then were seeded in the upper filter of a 24-well Transwell chamber (351184, Corning Incorporation, Corning, NY, USA), which was pre-coated with diluted Matrigel $(1: 8 ; 354234$, Corning Incorporation, USA). The medium with $10 \%$ FBS in the lower chamber was used as a source of chemoattractants. Incubated at $37^{\circ} \mathrm{C}$ for $48 \mathrm{~h}$, cells passing through the membrane were fixed with 4\% paraformaldehyde (P0099, Beyotime Biotechnology, Shanghai, China) at $4{ }^{\circ} \mathrm{C}$ for $30 \mathrm{~min}$ and then stained with $0.1 \%$ crystal violet (C0121, Beyotime Biotechnology, China) for $30 \mathrm{~min}$ at room temperature. Six visual fields were randomly selected from each room for counting by XSP-19C inverted biological microscope (magnification: 200x).

Cell apoptosis assay. Annexin-V-FITC Apoptosis Detection Kit (C1062S, Beyotime Biotechnology, China) was employed to evaluate the cell apoptosis. After trypsin digestion, cells centrifuged at $1,000 \times \mathrm{g}$ for $5 \mathrm{~min}$ were harvested and resuspended in PBS. Afterward, cells $\left(5 \times 10^{5}\right.$ cells) were centrifuged at $1,000 \times \mathrm{g}$ for another $5 \mathrm{~min}$, following which cells were resuspended in the binding buffer. Annexin V-FITC $(5 \mu \mathrm{l})$ and PI $(10 \mu \mathrm{l})$ were added to the cell solution and mixed well in a dark room for $15 \mathrm{~min}$ at room temperature. The apoptosis rate was analyzed through a flow cytometer (CytoFLEX, Beckman Coulter, Inc., Brea, CA, USA). 
Western blot. With total protein isolated through radioimmunoprecipitation assay (RIPA) lysis buffer (R0010, Beijing Solarbio Science \& Technology Co., Ltd., China), cells were centrifuged at $12,000 \times \mathrm{g}$ at $4^{\circ} \mathrm{C}$ for $10 \mathrm{~min}$ and the supernatant was collected. Total protein concentration was assessed by Pierce" Rapid Gold BCA Protein Assay Kit (A53227, Thermo Fisher Scientific, USA). Equal contents of protein and ColorMixed Protein Marker (11-180KD, PR1910, Beijing Solarbio Science\&Technology Co., Ltd., China) were separated with SDS-polyacrylamide gel electrophoresis (SDS-PAGE) with SDS-PAGE Gel Preparation Kit (P0012AC, Beyotime Biotechnology, China), subsequent to which cells were transferred to polyvinylidene fluoride (PVDF) membranes (88585, Thermo Fisher Scientific, USA) blocked in 5\% non-fat milk (D8340, Beijing Solarbio Science \& Technology Co., Ltd., China) at room temperature for $1 \mathrm{~h}$ and then incubated at $4{ }^{\circ} \mathrm{C}$ with anti-Cyclin D1 (1:10,000; ab134175, Abcam, Cambridge, MA, USA), anti-matrix metalloprotein (MMP)-7 (1:1,000; ab207299, Abcam, USA), anti-MMP-9 ( $1 \mu \mathrm{g} / \mathrm{ml}$; ab73734, Abcam, USA), anti-GAPDH (1:500; ab8245, Abcam, USA), anti-phosphorylation (p)-IкBa (1:1,000; \#2859, CST, Danvers, MA, USA), anti-pp65 (1:2,000; ab86299, Abcam, USA) and anti-p65 (0.5 $\mu \mathrm{g} / \mathrm{ml}$; ab16502, Abcam, USA). After overnight, membranes were washed four times with Tris-buffered saline containing Tween 20 (TBST; ST673, Beyotime Biotechnology, China), following which the membranes were incubated with the corresponding secondary antibodies conjugated to Horseradish Peroxidase (HRP; ab6721, 1:5,000; Abcam, USA) for $1 \mathrm{~h}$ at room temperature and rinsed five times with TBST for $5 \mathrm{~min}$. The proteins were visualized using electrochemiluminescence (ECL) reagent (PE0010, Beijing Solarbio Science\&Technology Co., Ltd., China) through a chemiluminescence system (SH-Focus523, Shenhua Bio. Co., Ltd., Hangzhou, China, http://www.shenhuabio.cn/index.php). ImageJ software, version 1.48 (National Institutes of Health, Bethesda, MD, USA) was employed for analyzing grey value of protein bands on blots.

Table 1. Primer sequences used for quantitative reverse transcriptionpolymerase chain reaction ( $q R T-P C R)$.

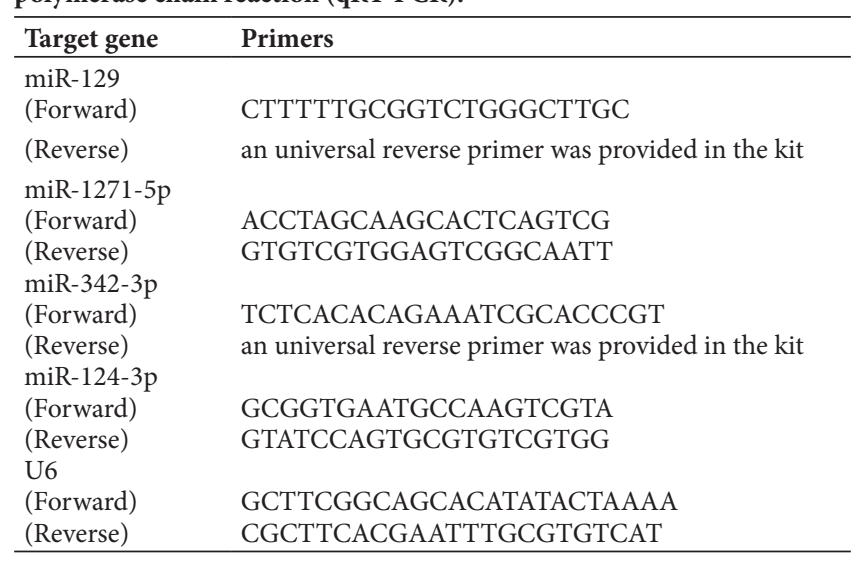

Quantitative reverse transcription-polymerase chain reaction (qRT-PCR). Total miRNA was respectively extracted using PureLink ${ }^{\mathrm{Tm}}$ miRNA Isolation Kit (K157001, Thermo Fisher Scientific, USA). The cDNAs of miR-129 and miR-342-3p were synthesized through reverse transcription in HG TaqMan miRNA Synthesis Kit (D1803, HaiGene, Harbin, China, http://www.haigene.cn/) while cDNAs of miR-1271-5p and miR-124-3p were synthesized using PrimeScript" RT reagent Kit (Perfect Real Time) (RR037A, Takara Bio, Inc., Otsu, Japan). The ABI 7300 real-time fluorescence quantitative PCR instrument (Thermo Fisher Scientific, USA) was utilized for the amplification of cDNAs. The quantitative real-time PCR of miR-129 and miR-342-3p was presented using HG TaqMan miRNA PCR Kit (TAP02445, HaiGene, China) with the conditions including $95^{\circ} \mathrm{C}$ for $15 \mathrm{~min}$, 40 cycles of $95^{\circ} \mathrm{C}$ for $10 \mathrm{~s}$, and $60^{\circ} \mathrm{C}$ for $30 \mathrm{~s}$. A universal reverse primer used miR-129 and miR-342-3p for was provided in the kit. As for miR-1271-5p and miR-124-3p, Hieff UNICON ${ }^{*}$ Universal Blue qPCR SYBR Green Master Mix (11184ES03, Yeasen Biotech Co., Ltd., Shanghai, China) was adopted to trace its real-time PCR following a condition of a thermal cycling program: pre-denaturation at $95^{\circ} \mathrm{C}$ for $30 \mathrm{~s}$, followed by 40 cycles of $95^{\circ} \mathrm{C}$ for $3 \mathrm{~s}$ and $60^{\circ} \mathrm{C}$ for 20 s. The primer sequences (Shanghai GenePharma Co., Ltd., China) were listed in Table 1 , as the universal reverse primers of miR-129 and miR-342-3p were provided in the kit. U6 served as the internal control for miRNA. Relative expression levels were calculated by the $2^{-\triangle \Delta \mathrm{CT}}$ relative quantification method [24].

Statistical analysis. All experiments were repeated independently at least three times. Statistical analysis was detected through SPSS 20.0 software (SPSS Inc., Chicago, IL, USA). Data were presented as means \pm standard deviation. One-way ANOVA was utilized to compare multiple groups with Dunnett's post hoc test. A statistically significant difference can be accepted when $\mathrm{p}<0.05$.

\section{Results}

Magnolol suppressed the viability and migration of MM cells. With the concentration of magnolol increasing, no significant difference of cell viability in nPCs was observed among groups (Figure 1A), while the cell viability of U266 and LP1 cells at 24 and $48 \mathrm{~h}$ decreased compared with the control groups (Figures $2 \mathrm{~B}, 2 \mathrm{C}, \mathrm{p}<0.05$ ), implicating that magnolol suppressed $\mathrm{MM}$ cell development in a dosedependent manner. Additionally, a marked reduction of cell migration rate was observed in magnolol-treated U266 and LP1 cells compared with the control group (Figures 1D, 1E, $\mathrm{p}<0.01)$.

Magnolol inhibited the invasion while advanced apoptosis of MM cells. As the magnolol concentration rose, the invasion rates of U266 and LP1 cells declined in comparison with the control group (Figures 2A, 2B, $\mathrm{p}<0.001$ ), whereas the opposite result was presented during 
A

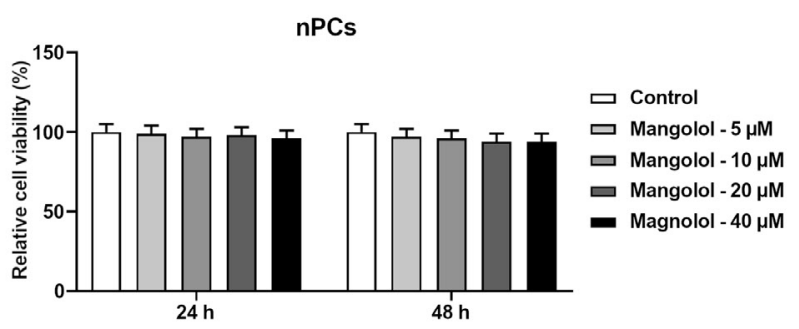

B

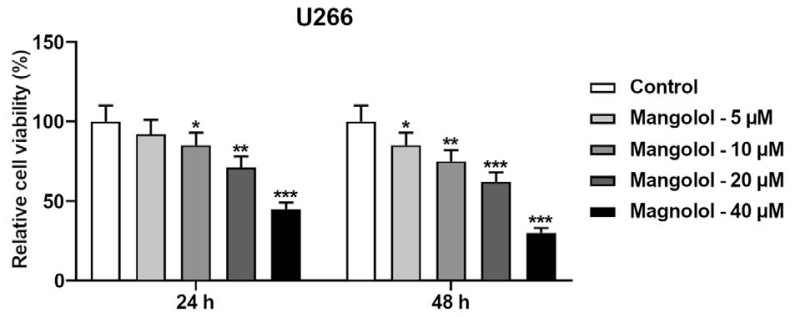

C
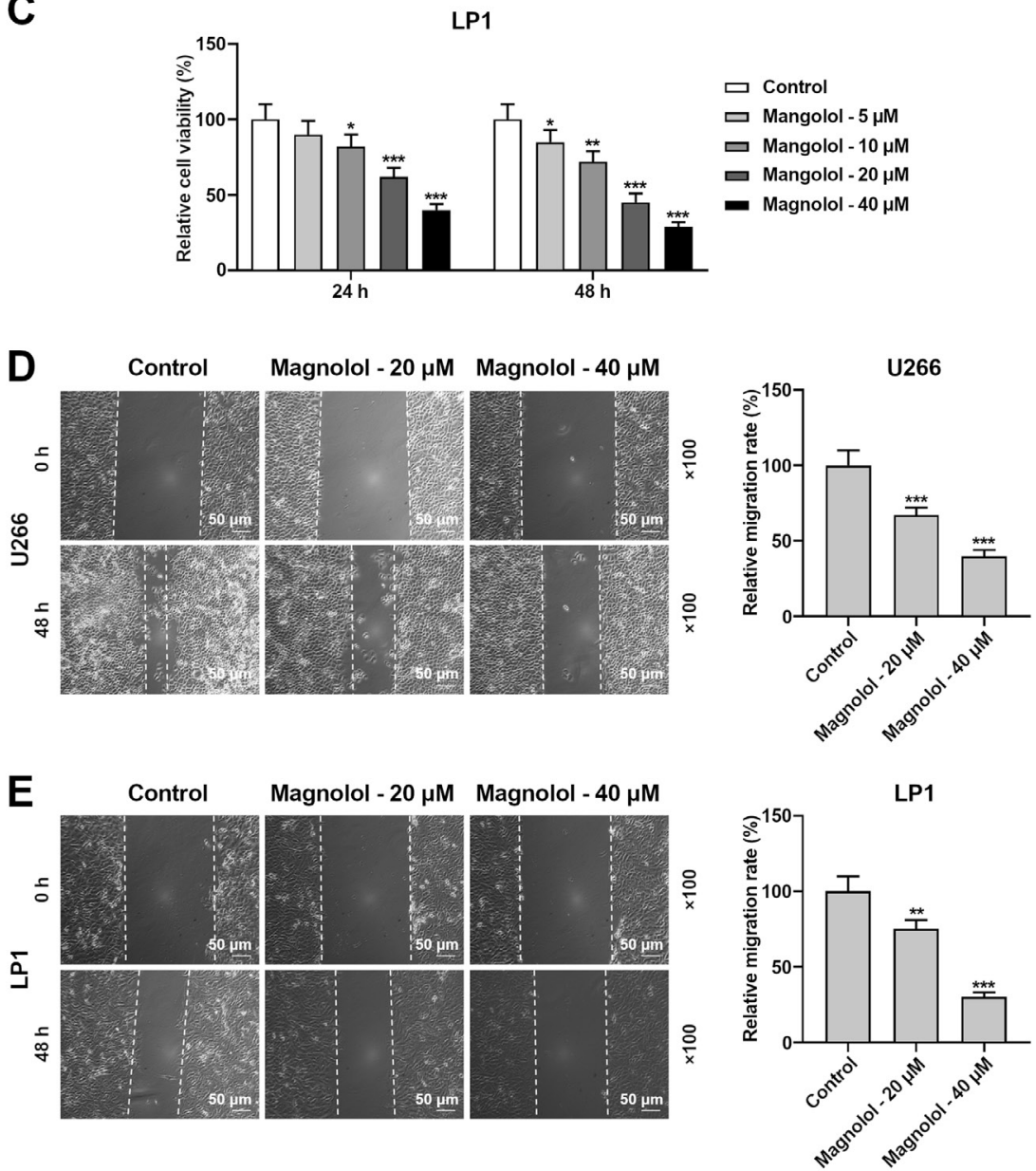

Figure 1. Magnolol suppressed the viability and migration of multiple myeloma (MM) cells. A-C) Cell viability at 24 and $48 \mathrm{~h}$ of normal plasma cells (nPCs, A), U266 (B), and LP1 cells (C) was detected by the Cell Counting Kit-8 (CCK-8) assay after the treatment with magnolol. D, E) Migration rate of U266 (D) and LP1 cells (E) was assessed through a wound healing assay after the treatment with magnolol. ${ }^{\star} p<0.05 \mathrm{vs}$. control group, ${ }^{\star *} p<0.01 \mathrm{vs.}$ control group, ${ }^{* *} \mathrm{p}<\mathbf{0 . 0 0 1}$ vs. control group. All experiments were repeated independently at least three times. Data are shown as the mean \pm standard deviations. 
A

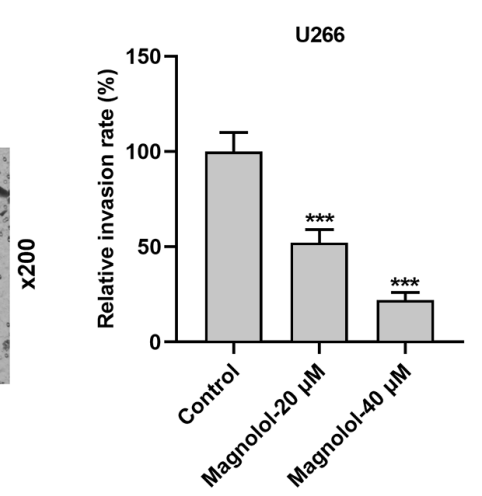

B
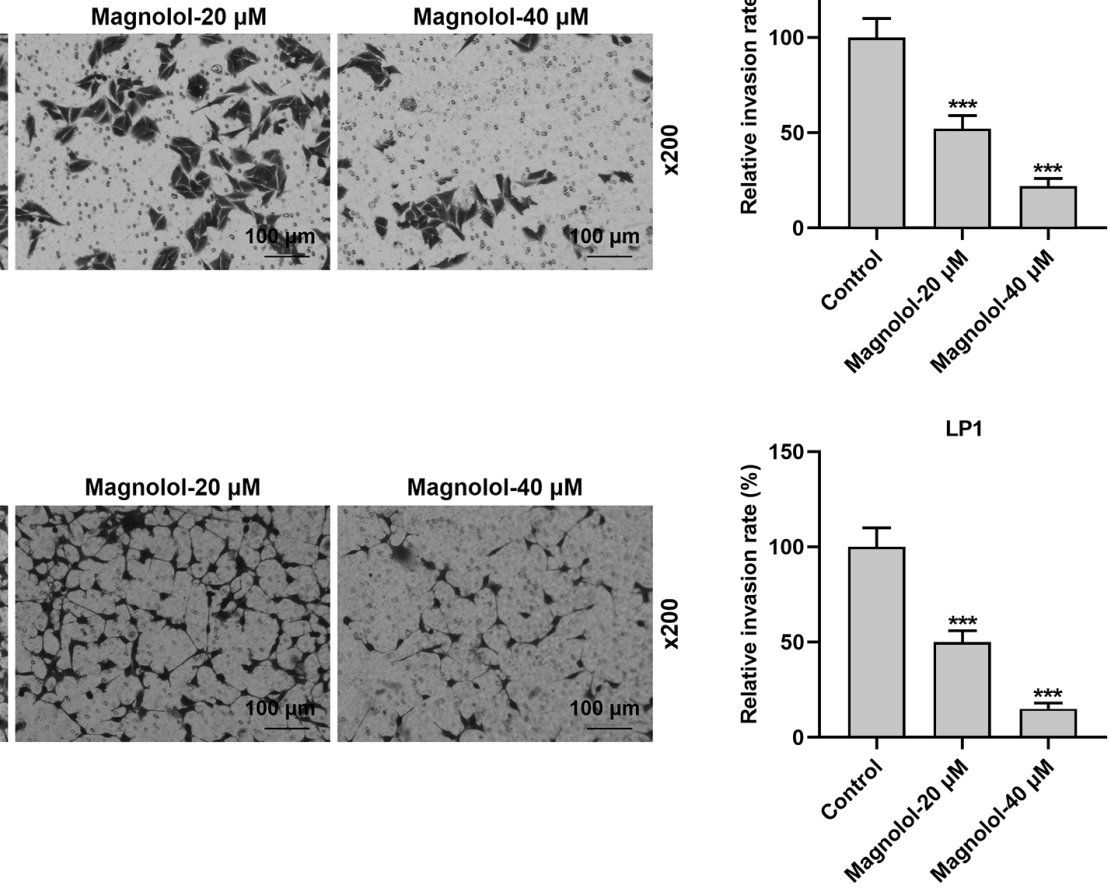

C
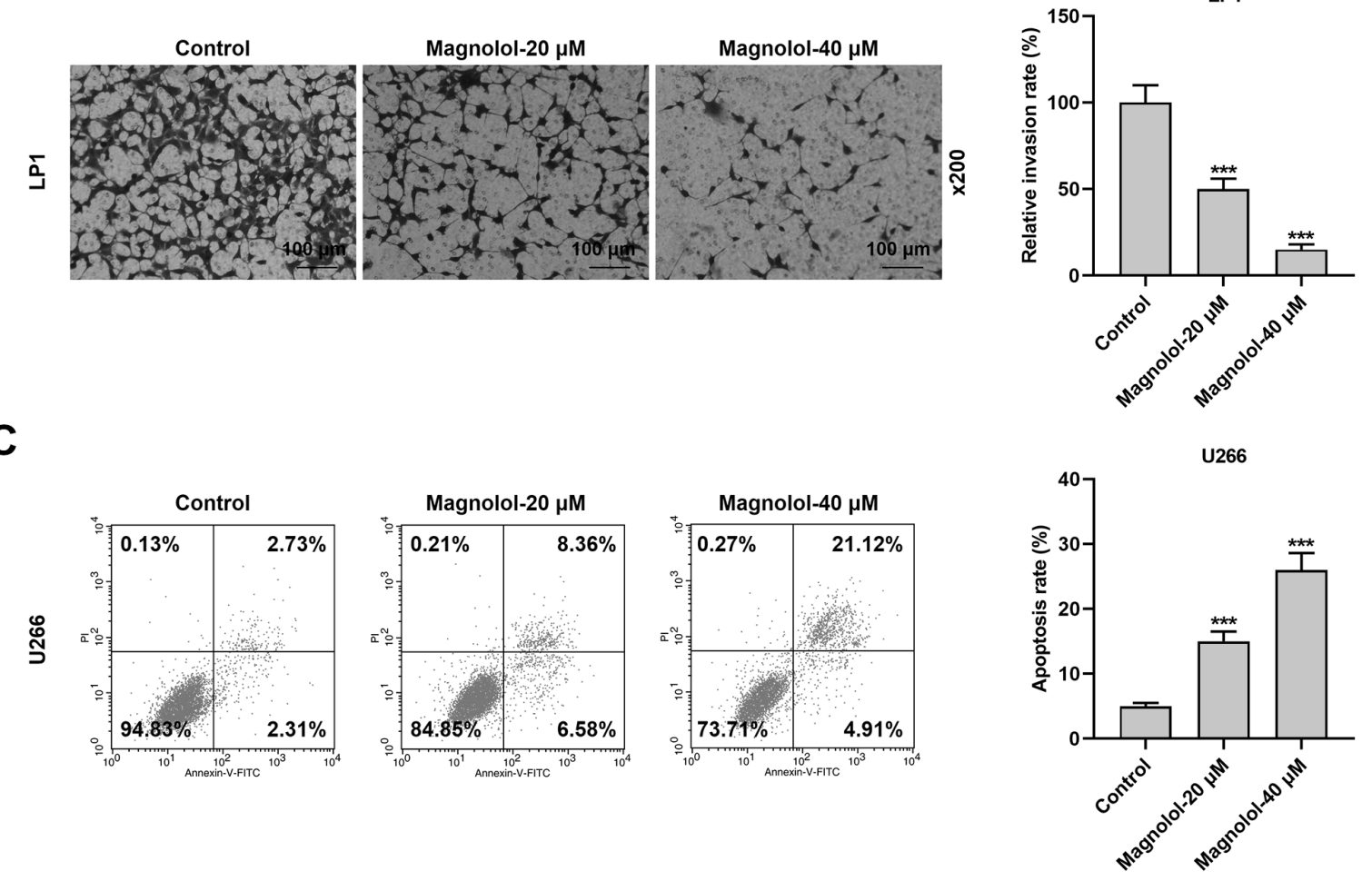

D
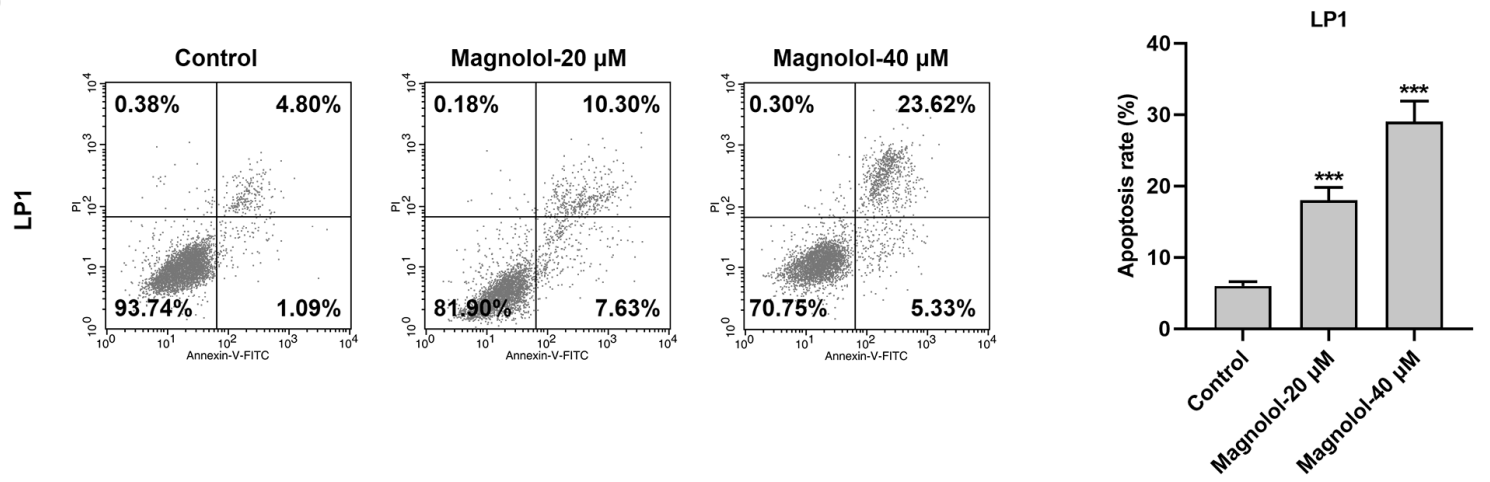

Figure 2. Magnolol inhibited the invasion while advanced apoptosis of multiple myeloma (MM) cells. A, B) Invasion rate of U266 (A) and LP1 cells (B) was assessed through the Transwell invasion assay after the treatment with magnolol. C, D) Apoptosis rate of U266 (C) and LP1 cells (D) was evaluated using Annexin-V-FITC Apoptosis Detection Kit with flow cytometry after the treatment with magnolol. ${ }^{* *} p<0.001$ vs. control group. All experiments were repeated independently at least three times. Data are shown as the mean \pm standard deviations. 
the cell apoptosis assay (Figures 2C, 2D, p<0.001), suggesting magnolol inhibited MM cell invasion and advanced cell apoptosis of MM.

Magnolol repressed Cyclin D1 and MMPs expression of MM cells. When treated with magnolol, U266 and LP1 cells showed lower expression of Cyclin D1, MMP-7, and MMP-9 than the control group (Figures 3A, 3B, p<0.05), with the increased magnolol concentration enhancing inhibitory effect on Cyclin D1, MMP-7, and MMP-9 expression (Figures 3A, 3B, p<0.05).

Magnolol increased the viability of MM cells via upregulating miR-129. miR-129 level of U266 and LP1 cells significantly was increased after treatment of magnolol compared with the control group (Figures $4 \mathrm{~A}, 4 \mathrm{~B}, \mathrm{p}<0.001$ ), and higher miR-129 expression was presented in the group treated with a higher concentration of magnolol (Figures 4A, 4B, p<0.001), as the expression level of miR-1271-5p, miR-342-3p, and miR-124-3p showed no significant difference (Figures 4A, $4 \mathrm{~B}$ ), which suggested a possible relation between magnolol and miR-129. In order to further explore the mechanism of magnolol, the miR-129 inhibitor was transfected into U266 and LP1 cells. It was observed that miR-129 expression only slightly reduced in the group of cells transfected with miR-129 inhibitor (Figures 4C, 4D). And a higher miR-129 level of U266 and LP1 cells was found in the magnolol-40 group than the control group (Figures 4E, 4F, $\mathrm{p}<0.001$ ). Besides, both U266 and LP1 cells had declined cell viability in the magnolol-40 group compared with the control group (Figures 4G, 4H, p<0.001), whereas cells in the magnolol-40 + miR-129 inhibitor group showed higher cell viability than the magnolol-40 + inhibitor control group (Figures $4 \mathrm{G}, 4 \mathrm{H}$, $\mathrm{p}<0.001$ ).

Magnolol suppressed the migration and invasion of MM cells via upregulating miR-129. In comparison with the control group, cell migration and invasion rates of U266 and LP1 cells decreased in the magnolol-40 group (Figures 5A, $5 \mathrm{D}, \mathrm{p}<0.001)$. In addition, cells in the group with the treatment of magnolol-40 and transfection of miR-129 inhibitor greatly increased migration and invasion rates compared with the group treated with magnolol-40 and transfected with inhibitor control (Figures 5A, 5D, p<0.001).

Magnolol repressed Cyclin D1 and MMPs expression of MM cells via upregulating miR-129. Through the analysis of western blot, a lower protein expression of Cyclin D1, MMP-7, and MMP-9 in U266 and LP1 cells was presented in the group magnolol-40 than the control group (Figures 6A, $6 \mathrm{~B}, \mathrm{p}<0.001$ ), whereas Cyclin D1, MMP-7, and MMP-9 protein levels were upregulated in magnolol-40 + miR-129
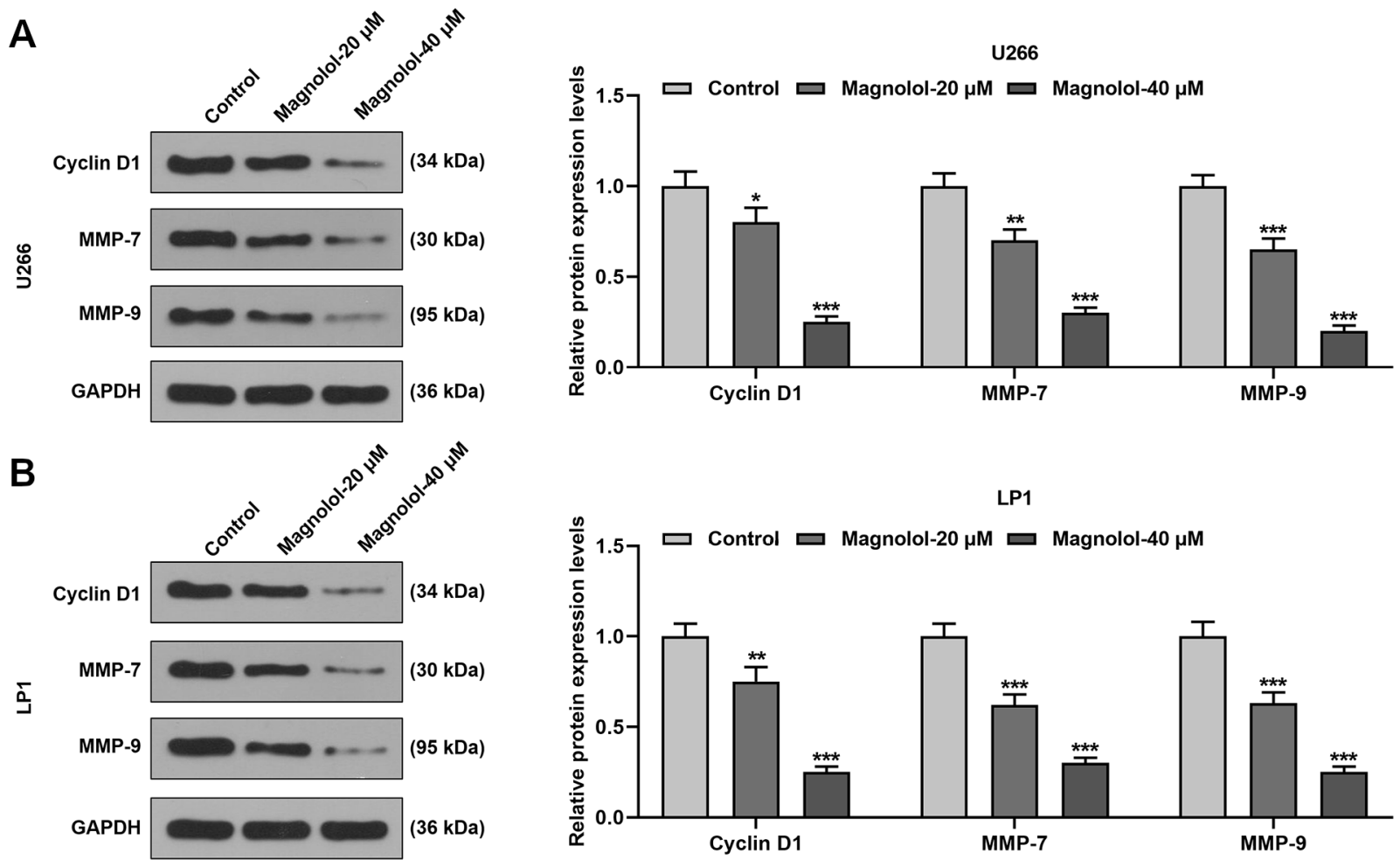

Figure 3. Magnolol repressed Cyclin D1 and matrix metalloproteins (MMPs) expression of multiple myeloma (MM) cells. A, B) Relative protein expression levels of Cyclin D1, MMP-7, and MMP-9 in U266 (A) and LP1 cells (B) were tested by western blot after the treatment with magnolol. ${ }^{* *}$ p $<0.01$ vs. control group, ${ }^{* * *} \mathrm{p}<0.001$ vs. control group. All experiments were repeated independently at least three times. Data are shown as the mean \pm standard deviations. 
A

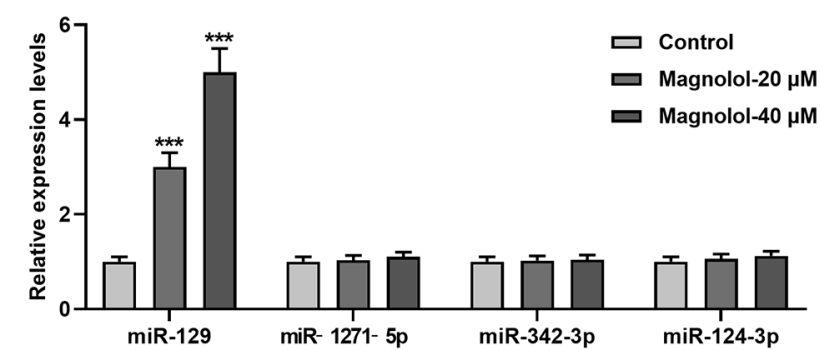

C

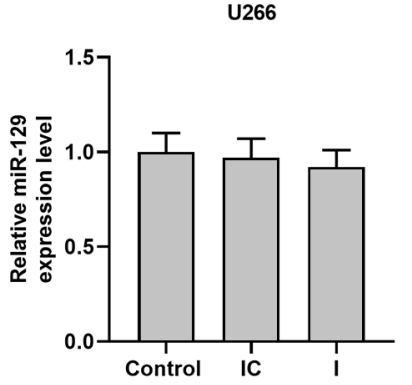

F

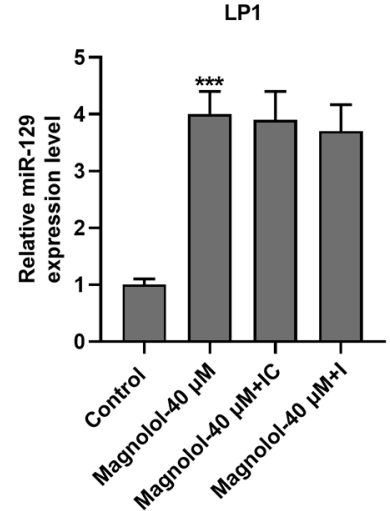

B

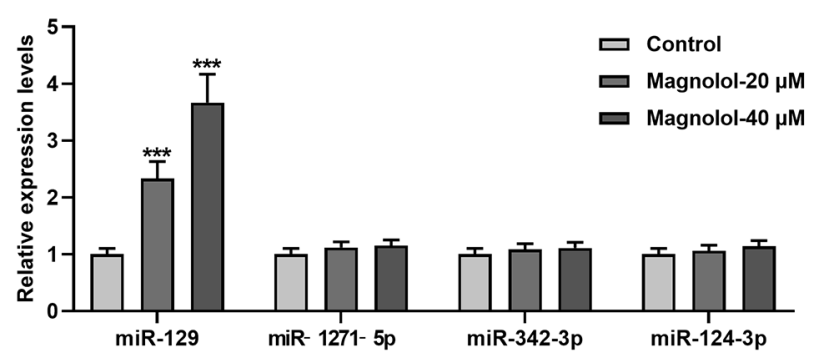

LP1

E
D

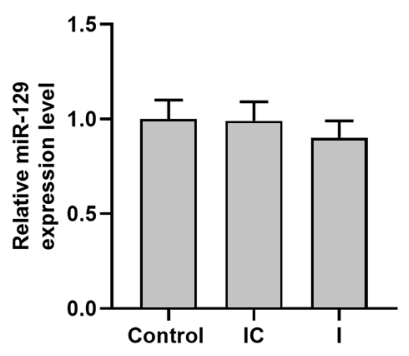

G

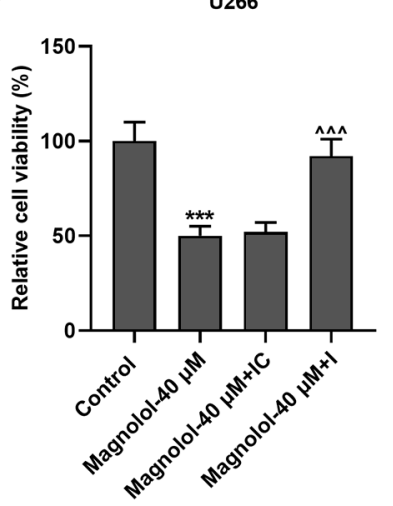

H
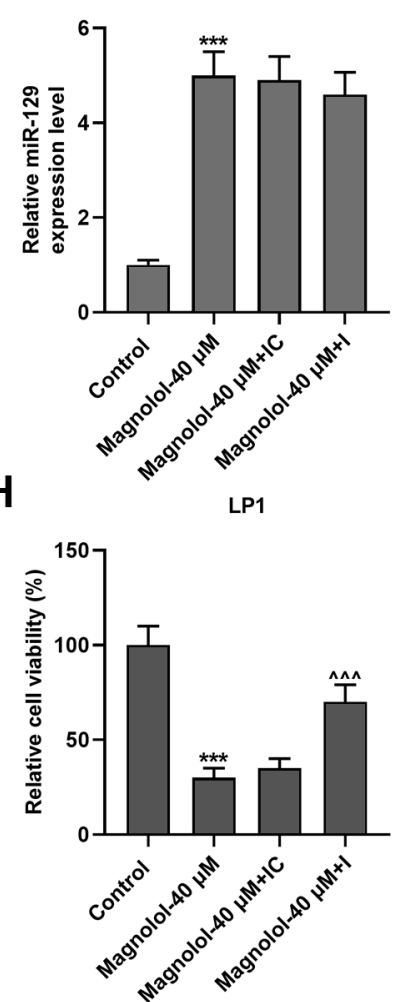

Figure 4. Magnolol increased the viability of multiple myeloma (MM) cells via upregulating miR-129. A, B) Relative expression levels of miR-129, miR1271-5p, miR-342-3p, and miR-124-3p in U266 (A) and LP1 cells (B) were detected by quantitative reverse transcription-polymerase chain reaction (qRT-PCR) after the treatment with magnolol. C, D) Relative expression levels of miR-129 in U266 (C) and LP1 cells (D) were detected by qRT-PCR after the transfection of the miR-129 inhibitor. E, F) Relative expression levels of miR-129 in U266 (E) and LP1 cells (F) were detected by qRT-PCR after the treatment of magnolol and the transfection of the miR-129 inhibitor. G, H) Cell viability of U266 (G) and LP1 cells (H) was detected by the Cell Counting Kit-8 (CCK-8) assay after the treatment of magnolol and the transfection of the miR-129 inhibitor. ${ }^{\star * *} \mathrm{p}<0.001$ vs. control group, $\wedge \wedge \wedge$ p $<0.001$ vs. magnolol-40 + inhibitor control (IC) group. All experiments were repeated independently at least three times. Data are shown as the mean \pm standard deviations.

inhibitor group compared with the magnolol-40 + inhibitor control group (Figures 6A, 6B, $\mathrm{p}<0.001$ ).

Magnolol inhibited the activation of the NF- $\mathrm{BB}$ signaling pathway via upregulating miR-129 in MM cells. Cells in the magnolol-40 group greatly reduced the protein expression level of $\mathrm{p}-\mathrm{I} \kappa \mathrm{B} \alpha$ and $\mathrm{p}-\mathrm{p} 65$ with a declined ratio of p-p65 to p65 compared with the control group (Figures 7A, $7 \mathrm{~B}, \mathrm{p}<0.001)$, as higher $\mathrm{p}-\mathrm{I} \kappa \mathrm{B} \alpha$ and $\mathrm{p}$-p65 protein expression with an increased ratio of p-p65 to p65 were presented in cells treated with magnolol-40 and transfected with the
miR-129 inhibitor in comparison with the group treated with magnolol-40 and transfected with inhibitor control (Figures 7A, 7B, p<0.001).

\section{Discussion}

MM is the second most common hematologic malignancy, which cannot be cured up to now [25]. Accumulating evidence has revealed the pharmacological efficiency of magnolol against various kinds of cancers [14-18]. Never- 
A

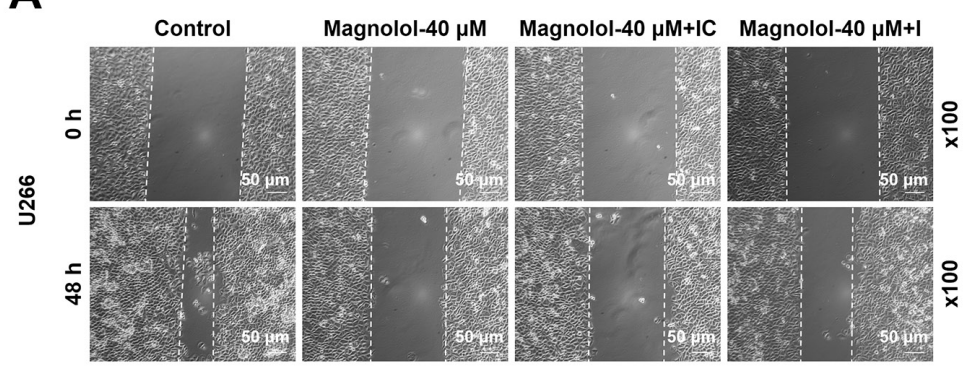

B

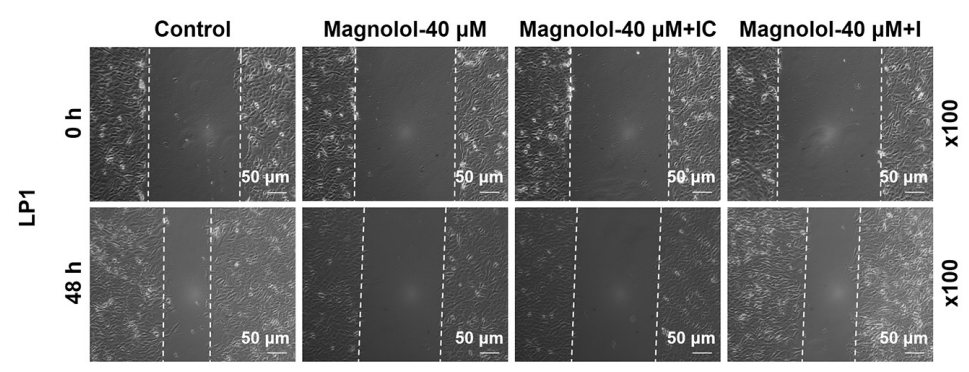

C

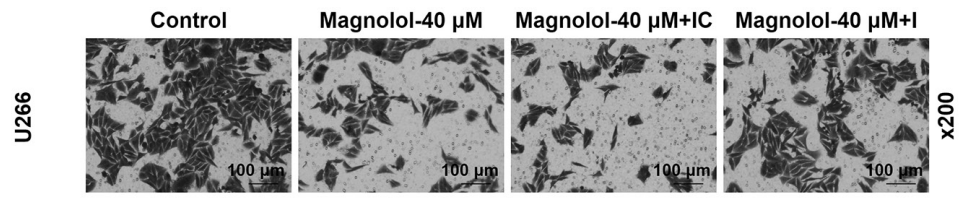

D

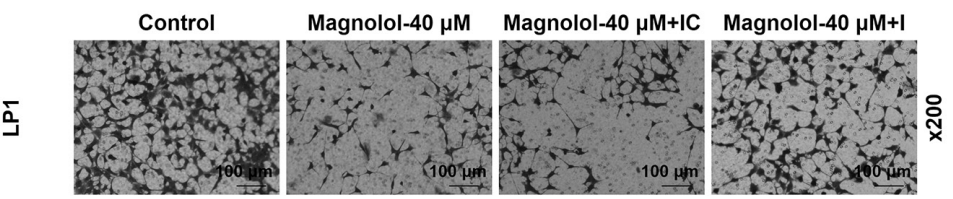

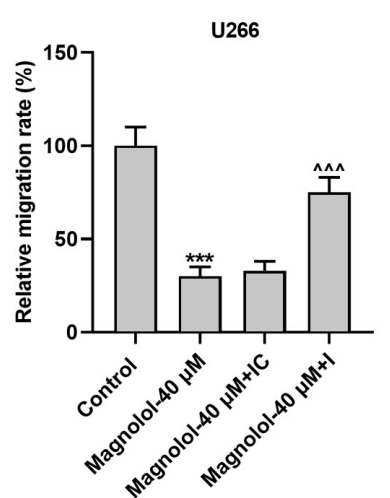

L1

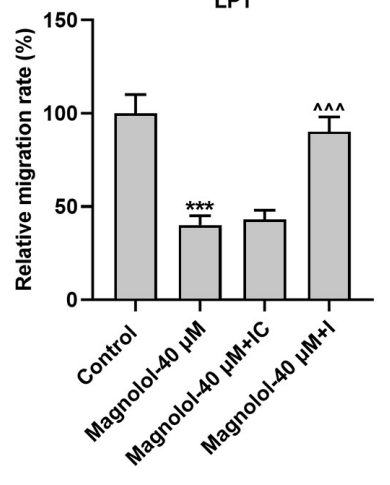

U266

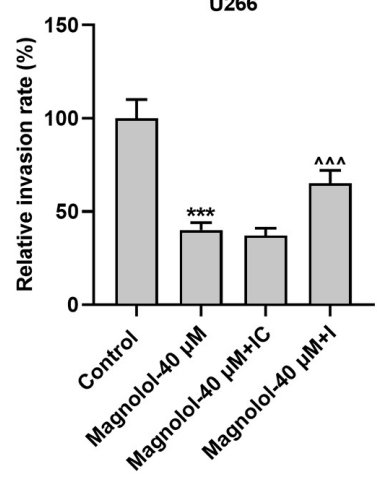

LP1

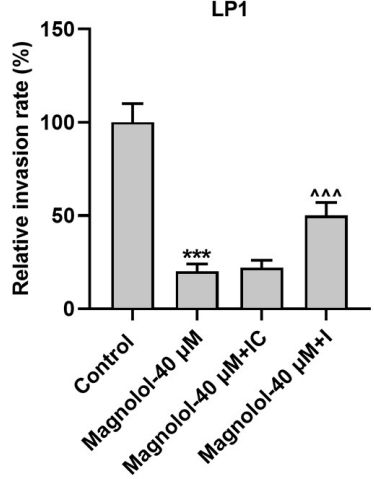

Figure 5. Magnolol suppressed the migration and invasion of multiple myeloma (MM) cells via upregulating miR-129. A, B) Migration rate of U266 (A) and LP1 cells (B) was assessed through a wound healing assay after the treatment of magnolol and the transfection of the miR-129 inhibitor. C, D) Invasion rate of U266 (C) and LP1 cells (D) was assessed through the Transwell invasion assay after the treatment of magnolol and the transfection of the miR-129 inhibitor. ${ }^{\star * *} \mathrm{p}<0.001$ vs. control group, $\wedge \wedge \wedge p<0.001$ vs. magnolol- $40+$ inhibitor control (IC) group. All experiments were repeated independently at least three times. Data are shown as the mean \pm standard deviations. 

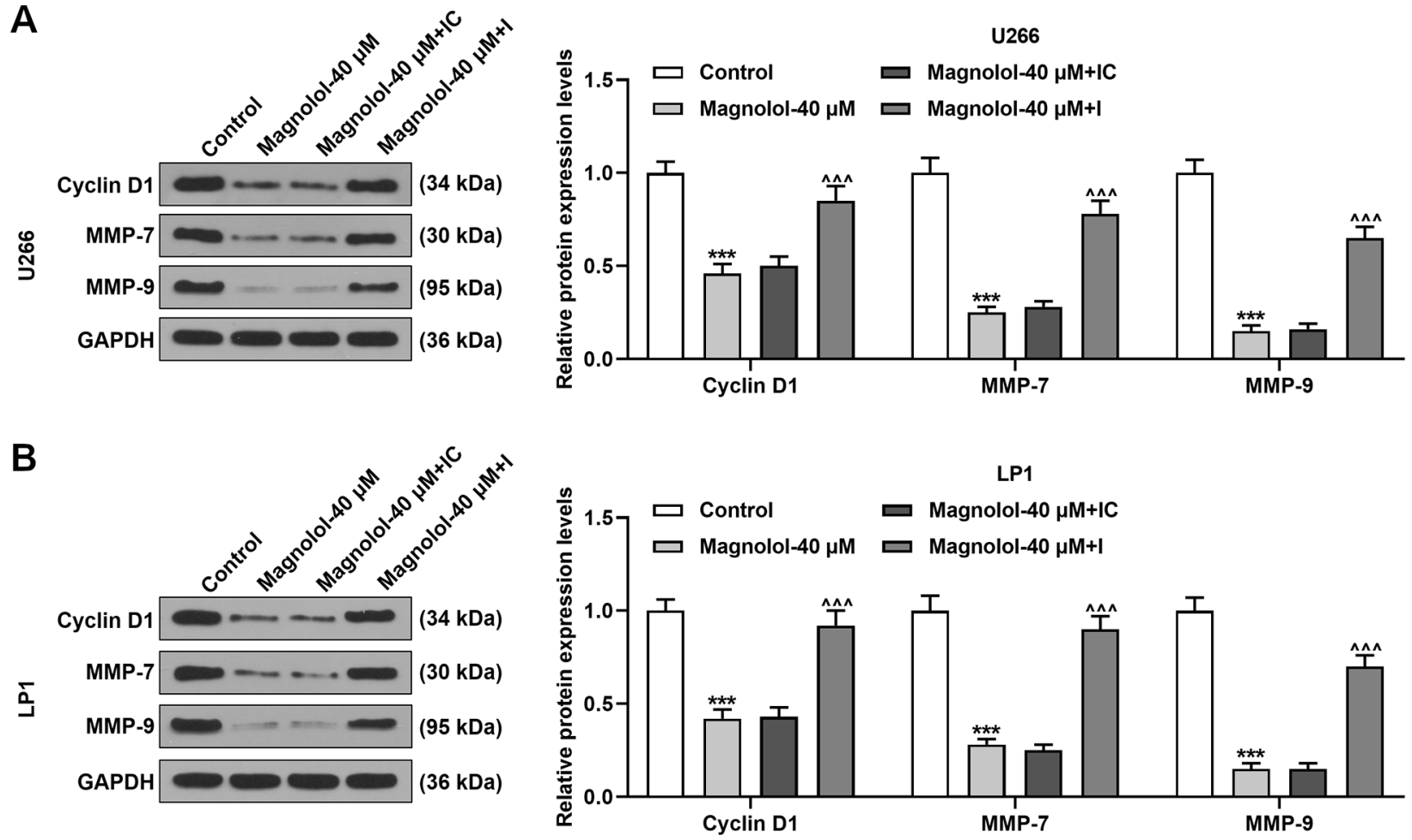

Figure 6. Magnolol repressed Cyclin D1 and matrix metalloproteins (MMPs) expression of multiple myeloma (MM) cells via upregulating miR-129. A, B) Relative protein expression levels of Cyclin D1, MMP-7, and MMP-9 in U266 (A) and LP1 cells (B) were tested by western blot after the treatment of magnolol and the transfection of the miR-129 inhibitor. ${ }^{* *} p<0.001$ vs. control group, ${ }^{\wedge \wedge} \wedge p<0.001$ vs. magnolol-40 + inhibitor control (IC) group. All experiments were repeated independently at least three times. Data are shown as the mean \pm standard deviations.

theless, the role and mechanism of magnolol on $\mathrm{MM}$ is still unknown. miR-129, belonging to the miRNA class, has shown its suppression on cell development of various malignant tumors [21-23]. In addition, downregulation of miR-129 has been observed in MM, with the overexpressed miR-129 inhibiting cell multiplication while promoting cell apoptosis of MM [10]. Hence, we supposed that magnolol might modulate MM cells by regulating miR-129. And this work determined the effect of magnolol on MM and its mechanism of action.

At first, we explored the effect of magnolol on MM cells. In agreement with the study about the influence of magnolol on osteosarcoma [18], our results showed MM cell viability greatly decreased with the concentration of magnolol rising, whereas the cell viability of nPCs was largely unaffected. This suggests a dose-dependent manner during the suppression of magnolol on MM cell viability as well as adds the possibility of magnolol as a safe biological compound for MM therapy in clinics as magnolol was specific for MM cells without harming normal cells. Furthermore, cell migration and invasion rates were negatively correlative to magnolol concentration while cell apoptosis had a positive correlation to magnolol, which was consistent with reports about magnolol functioning on a number of cancers including
Ewing sarcoma, osteosarcoma, cholangiocarcinoma, breast cancer, hepatocellular carcinoma, lung cancer, glioblastoma, prostate cancer, and thyroid carcinoma $[14,17,18$, 26-32].

Cyclin D1, as a cell cycle-related protein regulating cyclindependent kinase, participates in cell apoptosis during the progression of many cancers $[33,34]$. MMPs are a group of zinc $(\mathrm{Zn})$ containing enzymes and MMP-9 is involved in degradation and remodeling of extracellular matrix (ECM), which connects with epithelial-mesenchymal transition (EMT), implicated in cell metastasis as well as many other progressions of various cancers. As for MMP-7, it has been reported that MMP-7 is capable of destroying basement membrane components, which is a key point of cell invasion and metastasis in cancers. And the degradation of the basement membrane, including the ECM, plays a significant part in invasion [35-40]. In our researches, corresponding to other experiments about the effect of magnolol on osteosarcoma and cholangiocarcinoma cells $[18,31]$, we discovered that the protein expressions of Cyclin D1, MMP-7, and MMP-9 were inhibited when MM cells treated with magnolol. Therefore, magnolol may inhibit myeloma growth and metastasis through downregulating Cyclin D1, MMP-7, and MMP-9. 

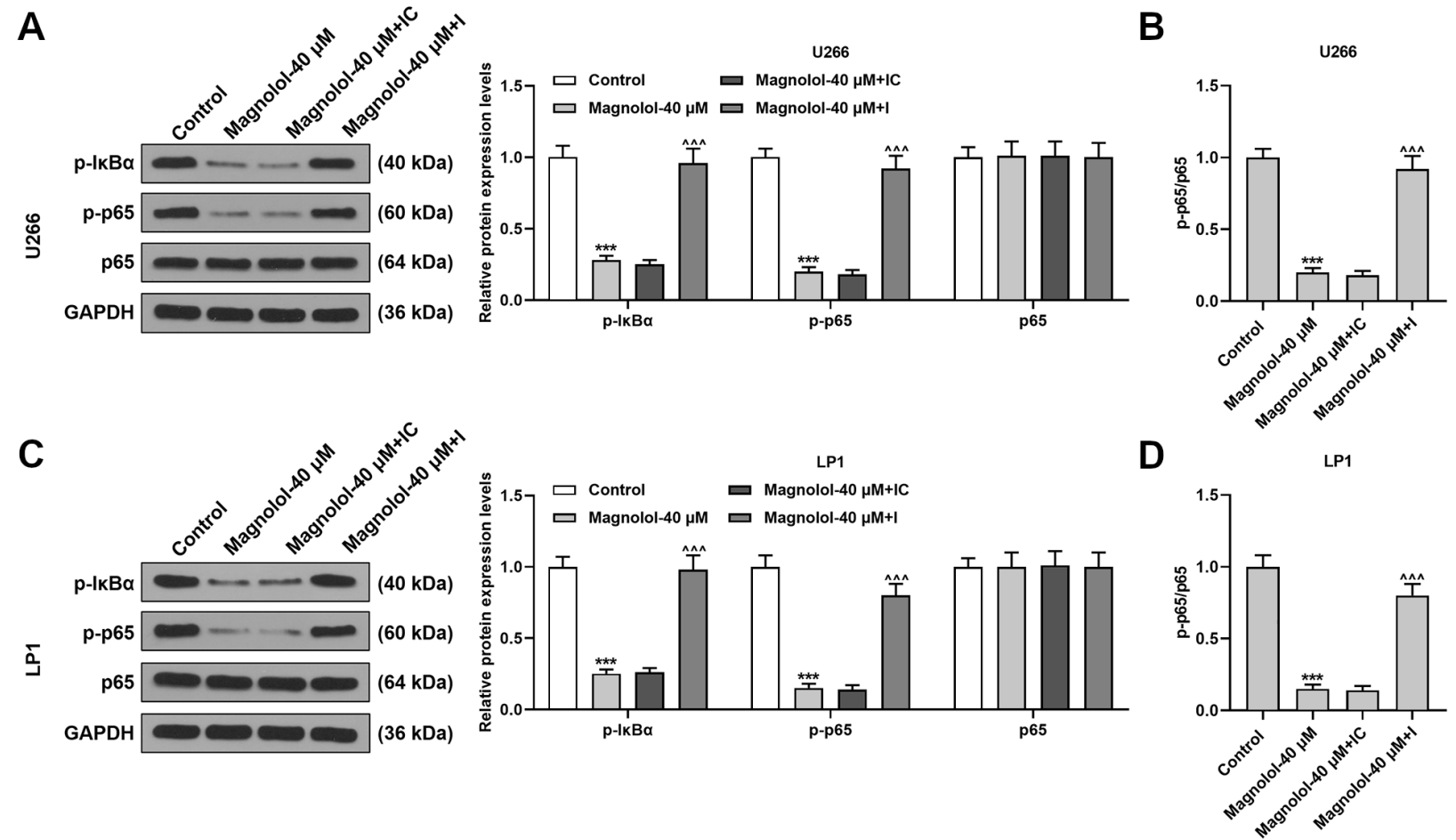

Figure 7. Magnolol inhibited the activation of the NF- $\mathrm{kB}$ signaling pathway via upregulating miR-129 in multiple myeloma (MM) cells. A, B) Relative protein expression levels of phosphorylation (p)-IkBa, p-p65, and p65 as well as the ratio of p-p65 to p65 in U266 cells were assessed through western blot after the treatment of magnolol and the transfection of the miR-129 inhibitor. C, D) Relative protein expression levels of p-IкBa, p-p65, and p65, as well as the ratio of p-p65 to p65 in LP1 cells, were assessed through western blot after the treatment of magnolol and the transfection of the miR-129 inhibitor. ${ }^{* *} p<0.001$ vs. control group, $\wedge \wedge \wedge p<0.001$ vs. magnolol-40 + inhibitor control (IC) group. All experiments were repeated independently at least three times. Data are shown as the mean \pm standard deviations.

At second, we looked into the mechanism of magnolol. It has been discovered that miR-1271-5p, miR-342-3p, and miR-124-3p are involved in the suppression of MM [41-46]. The results of qRT-PCR presented a marked upregulation of miR-129 in MM cells treated with magnolol while little difference occurred in the expression of miR-1271-5p, miR-342-3p, and miR-124-3p, indicating magnolol might target miR-129 during MM. In order to further determine whether magnolol realized its function by promoting miR-129 expression, we used the miR-129 inhibitor to transfect into MM cells. During the experiments, we found that magnolol increased miR-129 expression and decreased cell viability while the miR-129 inhibitor raised cell viability. Moreover, magnolol inhibited cell migration and invasion of MM, whereas miR-129 inhibitor counteracted the effect of magnolol. The same results were also performed in the detection of Cyclin D1, MMP-7, and MMP-9 protein expression levels through western blot. $\mathrm{NF}-\kappa \mathrm{B}$ is a critical factor whose activation connects with initiation and development in a number of cancers including MM $[47,48]$. P-IкBa and p65 appear to be the major forms of the activated NF- $\kappa B$ signaling pathway [49]. Consistent with a previous study about magnolol repressing the NF- $\mathrm{KB}$ activation of cholangiocarcinoma cells as well as miR-129 targeting NF- $\kappa B$ pathway in MM $[10,31]$, the results showed that magnolol suppressed activation of NF- $\kappa \mathrm{B}$ signaling pathway, as miR-129 inhibitor antagonized the function of magnolol.

Taken all together, the observation and analysis obtained in our experiments demonstrated the protective effects of magnolol against $\mathrm{MM}$ and showed its specific molecular mechanism, providing strong support for the function of magnolol against cancers and offering a promising and potential therapeutic target and drug for intervention and treatment of MM. However, there still exist some problems in our study. Experiments in vivo should be done in the following study to further confirm the conclusions of experiments in vitro. In the future, we will also investigate the function of magnolol in vivo for verification of the conclusion in this paper and continue to search for other targets of magnolol and their concrete mechanisms so that more possible therapies can be provided.

In summary, this work studied the effect of magnolol on MM and its mechanism of action. Magnolol did not suppress harm normal cells, but suppress cell migration and invasion, and induced cell apoptosis in MM via inhibition of the NF- $\kappa B$ signaling pathway by upregulating miR-129, suggesting magnolol with hypotoxicity might become a novel targeted therapeutic drug for MM. 
Acknowledgements: This work was supported by the Clinical Research Fund of Zhejiang Medical Association[2018zyc-A164].

\section{References}

[1] SHEN X, ZHANG Y, WU X, GUO Y, SHI W et al. Upregulated lncRNA-PCAT1 is closely related to clinical diagnosis of multiple myeloma as a predictive biomarker in serum. Cancer Biomark 2017; 18: 257-263. https://doi.org/10.3233/ CBM-160158

[2] ABRAMSON HN. Monoclonal Antibodies for the Treatment of Multiple Myeloma: An Update. Int J Mol Sci 2018; 19: 3924. https://doi.org/10.3390/ijms19123924

[3] KUMAR SK, RAJKUMAR V, KYLE RA, VAN DUIN M, SONNEVELD P et al. Multiple myeloma. Nat Rev Dis Primers 2017; 3: 17046. https://doi.org/10.1038/nrdp.2017.46

[4] SONNEVELD P, AVET-LOISEAU H, LONIAL S, USMANI S, SIEGEL D et al. Treatment of multiple myeloma with high-risk cytogenetics: a consensus of the International Myeloma Working Group. Blood 2016; 127: 2955-2962. https:// doi.org/10.1182/blood-2016-01-631200

[5] ANDRES M, FELLER A, ARNDT V. Trends of incidence, mortality, and survival of multiple myeloma in Switzerland between 1994 and 2013. Cancer Epidemiol 2018; 53: 105110. https://doi.org/10.1016/j.canep.2018.01.015

[6] KUMAR SK, CALLANDER NS, ALSINA M, ATANACKOVIC D, BIERMANN JS et al. Multiple Myeloma, Version 3.2017, NCCN Clinical Practice Guidelines in Oncology. J Natl Compr Canc Netw 2017; 15: 230-269. https://doi.org/10.6004/jnccn.2017.0023

[7] ZHOU M, ZHAO H, WANG Z, CHENG L, YANG L et al. Identification and validation of potential prognostic lncRNA biomarkers for predicting survival in patients with multiple myeloma. J Exp Clin Cancer Res 2015; 34: 102. https://doi. org/10.1186/s13046-015-0219-5

[8] GENG W, GUO X, ZHANG L, MA Y, WANG L et al. Resveratrol inhibits proliferation, migration and invasion of multiple myeloma cells via NEAT1-mediated Wnt/ $\beta$-catenin signaling pathway. Biomed Pharmacother 2018; 107: 484-494. https://doi.org/10.1016/j.biopha.2018.08.003

[9] PU J, HUANG H, SU J, YUAN J, CONG H et al. Decreased expression of long noncoding RNA XLOC_013703 promotes cell growth via NF- $\kappa \mathrm{B}$ pathway in multiple myeloma. IUBMB Life 2019; 71: 1240-1251. https://doi.org/10.1002/iub.2029

[10] SHEN X, KONG S, YANG Q, YIN Q, CONG H et al. PCAT1 promotes cell growth by sponging miR-129 via MAP3K7/ NF- $\kappa B$ pathway in multiple myeloma. J Cell Mol Med 2020; 24: 3492-3503. https://doi.org/10.1111/jcmm.15035

[11] LIU F, LUO G, XIAO Q, CHEN L, LUO X et al. Fucoidan inhibits angiogenesis induced by multiple myeloma cells. Oncol Rep 2016; 36: 1963-1972. https://doi.org/10.3892/ or.2016.4987

[12] QU J, ZHANG T, LIU J, SU Y, WANG H. Considerations for the Quality Control of Newly Registered Traditional Chinese Medicine in China: A Review. J AOAC Int 2019; 102: 689-694. https://doi.org/10.5740/jaoacint.18-0301
[13] LEE YJ, LEE YM, LEE CK, JUNG JK, HAN SB et al. Therapeutic applications of compounds in the Magnolia family. Pharmacol Ther 2011; 130: 157-176. https://doi. org/10.1016/j.pharmthera.2011.01.010

[14] LIU Y, CAO W, ZHANG B, LIU YQ, WANG ZY et al. The natural compound magnolol inhibits invasion and exhibits potential in human breast cancer therapy. Sci Rep 2013; 3: 3098. https://doi.org/10.1038/srep03098

[15] HWANG ES, PARK KK. Magnolol suppresses metastasis via inhibition of invasion, migration, and matrix metalloproteinase-2/-9 activities in PC-3 human prostate carcinoma cells. Biosci Biotechnol Biochem 2010; 74: 961-967. https:// doi.org/10.1271/bbb.90785

[16] KANG YJ, PARK HJ, CHUNG HJ, MIN HY, PARK EJ et al. Wnt/ $\beta$-catenin signaling mediates the antitumor activity of magnolol in colorectal cancer cells. Mol Pharmacol 2012; 82: 168-177. https://doi.org/10.1124/mol.112.078535

[17] LEE DH, SZCZEPANSKI MJ, LEE YJ. Magnolol induces apoptosis via inhibiting the EGFR/PI3K/Akt signaling pathway in human prostate cancer cells. J Cell Biochem 2009; 106: 1113-1122. https://doi.org/10.1002/jcb.22098

[18] ZHOU S, WEN H, LI H. Magnolol induces apoptosis in osteosarcoma cells via G0/G1 phase arrest and p53-mediated mitochondrial pathway. J Cell Biochem 2019; 120: 17067 17079. https://doi.org/10.1002/jcb.28968

[19] DRUSCO A, CROCE CM. MicroRNAs and Cancer: A Long Story for Short RNAs. Adv Cancer Res 2017; 135: 1-24. https://doi.org/10.1016/bs.acr.2017.06.005

[20] LIN S, GREGORY RI. MicroRNA biogenesis pathways in cancer. Nat Rev Cancer 2015; 15: 321-333. https://doi. org/10.1038/nrc3932

[21] DIAO Y, JIN B, HUANG L, ZHOU W. MiR-129-5p inhibits glioma cell progression in vitro and in vivo by targeting TGIF2. J Cell Mol Med 2018; 22: 2357-2367. https://doi. org/10.1111/jcmm.13529

[22] XU S, GE J, ZHANG Z, ZHOU W. MiR-129 inhibits cell proliferation and metastasis by targeting ETS1 via PI3K/ AKT/mTOR pathway in prostate cancer. Biomed Pharmacother 2017; 96: 634-641. https://doi.org/10.1016/j.biopha.2017.10.037

[23] ZENG A, YIN J, LI Y, LI R, WANG Z et al. miR-129-5p targets Wnt5a to block PKC/ERK/NF- $\mathrm{B}$ and JNK pathways in glioblastoma. Cell Death Dis 2018; 9: 394. https://doi. org/10.1038/s41419-018-0343-1

[24] LIVAK KJ, SCHMITTGEN TD. Analysis of relative gene expression data using real-time quantitative PCR and the 2(-Delta Delta C(T)) Method. Methods 2001; 25: 402-408. https://doi.org/10.1006/meth.2001.1262

[25] BOISE LH, KAUFMAN JL, BAHLIS NJ, LONIAL S, LEE KP. The Tao of myeloma. Blood 2014; 124: 1873-1879. https://doi.org/10.1182/blood-2014-05-578732

[26] CHEN LC, LEE WS. P27/Kip1 is responsible for magnolol-induced U373 apoptosis in vitro and in vivo. J Agric Food Chem 2013; 61: 2811-2819. https://doi.org/10.1021/ jf $400542 \mathrm{~m}$ 
[27] GAO T, XU H, JIA S, CAI Z, CHEN B et al. Magnolol induces human Ewing sarcoma SK-ES-1 cell apoptosis via the mitochondrial and death receptor pathways. Am J Transl Res 2020; 12: 1672-1682.

[28] HUANG SH, CHEN Y, TUNG PY, WU JC, CHEN KH et al. Mechanisms for the magnolol-induced cell death of CGTH W-2 thyroid carcinoma cells. J Cell Biochem 2007; 101: 1011-1022. https://doi.org/10.1002/jcb.21100

[29] TSAI JR, CHONG IW, CHEN YH, HWANG JJ, YIN WH et al. Magnolol induces apoptosis via caspase-independent pathways in non-small cell lung cancer cells. Arch Pharm Res 2014; 37: 548-557. https://doi.org/10.1007/s12272-0130232-1

[30] WANG YD, SUN XJ, YANG WJ, LI J, YIN JJ. Magnolol exerts anticancer activity in hepatocellular carcinoma cells through regulating endoplasmic reticulum stress-mediated apoptotic signaling. Onco Targets Ther 2018; 11: 5219-5226. https://doi.org/10.2147/OTT.S168887

[31] ZHANG FH, REN HY, SHEN JX, ZHANG XY, YE HM et al. Magnolol suppresses the proliferation and invasion of cholangiocarcinoma cells via inhibiting the NF- $\kappa \mathrm{B}$ signaling pathway. Biomed Pharmacother 2017; 94: 474-480. https:// doi.org/10.1016/j.biopha.2017.07.085

[32] ZHOU Y, BI Y, YANG C, YANG J, JIANG Y et al. Magnolol induces apoptosis in MCF-7 human breast cancer cells through G2/M phase arrest and caspase-independent pathway. Pharmazie 2013; 68: 755-762.

[33] HOU X, LIANG RB, WEI JC, XU Y, FU JH et al. Cyclin D1 expression predicts postoperative distant metastasis and survival in resectable esophageal squamous cell carcinoma. Oncotarget 2016; 7: 31088-31096. https://doi.org/10.18632/ oncotarget.9078

[34] CASTRO RE, AMARAL JD, SOLÁ S, KREN BT, STEER CJ et al. Differential regulation of cyclin D1 and cell death by bile acids in primary rat hepatocytes. Am J Physiol Gastrointest Liver Physiol 2007; 293: G327-334. https://doi. org/10.1152/ajpgi.00093.2007

[35] BIAŁKOWSKA K, MARCINIAK W, MUSZYŃSKA M, BASZUK P, GUPTA $S$ et al. Polymorphisms in MMP-1, MMP-2, MMP-7, MMP-13 and MT2A do not contribute to breast, lung and colon cancer risk in polish population. Hered Cancer Clin Pract 2020; 18: 16. https://doi. org/10.1186/s13053-020-00147-w

[36] JABŁOŃSKA-TRYPUĆ A, MATEJCZYK M, ROSOCHACKI S. Matrix metalloproteinases (MMPs), the main extracellular matrix (ECM) enzymes in collagen degradation, as a target for anticancer drugs. J Enzyme Inhib Med Chem 2016; 31: 177-183. https://doi.org/10.3109/14756366 .2016.1161620

[37] MALIK V, GARG S, AFZAL S, DHANJAL JK, YUN CO et al. Bioinformatics and Molecular Insights to Anti-Metastasis Activity of Triethylene Glycol Derivatives. Int J Mol Sci 2020; 21: 5463. https://doi.org/10.3390/ijms21155463

[38] KITOH T, YANAI H, SAITOH Y, NAKAMURA Y, MATSUBARA Y et al. Increased expression of matrix metalloproteinase-7 in invasive early gastric cancer. J Gastroenterol 2004; 39: 434-440. https://doi.org/10.1007/s00535-003-1316-3
[39] MIYATA Y, IWATA T, OHBA K, KANDA S, NISHIKIDO $M$ et al. Expression of matrix metalloproteinase-7 on cancer cells and tissue endothelial cells in renal cell carcinoma: prognostic implications and clinical significance for invasion and metastasis. Clin Cancer Res 2006; 12: 6998-7003. https://doi.org/10.1158/1078-0432.CCR-06-1626

[40] YAMAMOTO T, OSHIMA T, YOSHIHARA K, NISHI T, ARAI $H$ et al. Clinical significance of immunohistochemical expression of insulin-like growth factor-1 receptor and matrix metalloproteinase-7 in resected non-small cell lung cancer. Exp Ther Med 2012; 3: 797-802. https://doi.org/10.3892/ etm.2012.493

[41] CHEN X, LIU Y, YANG Z, ZHANG J, CHEN S et al. LINC01234 promotes multiple myeloma progression by regulating miR-124-3p/GRB2 axis. Am J Transl Res 2019; 11: 6600-6618.

[42] LI Z, WONG KY, CHAN GC, CHNG WJ, CHIM CS. Epigenetic silencing of EVL/miR-342 in multiple myeloma. Transl Res 2018; 192: 46-53. https://doi.org/10.1016/j. trsl.2017.11.005

[43] LIU N, FENG S, LI H, CHEN X, BAI S et al. Long noncoding RNA MALAT1 facilitates the tumorigenesis, invasion and glycolysis of multiple myeloma via miR-1271-5p/SOX13 axis. J Cancer Res Clin Oncol 2020; 146: 367-379. https:// doi.org/10.1007/s00432-020-03127-8

[44] RONCHETTI D, LIONETTI M, MOSCA L, AGNELLI L, ANDRONACHE A et al. An integrative genomic approach reveals coordinated expression of intronic miR-335, miR-342, and miR-561 with deregulated host genes in multiple myeloma. BMC Med Genomics 2008; 1: 37. https://doi. org/10.1186/1755-8794-1-37

[45] YANG X, HUANG H, WANG X, LIU H, LIU H et al. Knockdown of lncRNA SNHG16 suppresses multiple myeloma cell proliferation by sponging miR-342-3p. Cancer Cell Int 2020; 20: 38. https://doi.org/10.1186/s12935-020-1118-1

[46] YANG Y, CHEN L. Downregulation of lncRNA UCA1 facilitates apoptosis and reduces proliferation in multiple myeloma via regulation of the miR-1271-5p/HGF axis. J Chin Med Assoc 2019; 82: 699-709. https://doi.org/10.1097/ JCMA.0000000000000145

[47] MATTHEWS GM, DE MATOS SIMOES R, DHIMOLEA E, SHEFFER M, GANDOLFI S et al. NF- $\kappa$ B dysregulation in multiple myeloma. Semin Cancer Biol 2016; 39: 68-76. https://doi.org/10.1016/j.semcancer.2016.08.005

[48] PARK MH, HONG JT. Roles of NF- $\mathrm{BB}$ in Cancer and Inflammatory Diseases and Their Therapeutic Approaches. Cells 2016; 5: 15. https://doi.org/10.3390/cells5020015

[49] PETERSON JM, WANG DJ, SHETTIGAR V, ROOF SR, CANAN BD et al. NF- $\mathrm{BB}$ inhibition rescues cardiac function by remodeling calcium genes in a Duchenne muscular dystrophy model. Nat Commun 2018; 9: 3431. https://doi. org/10.1038/s41467-018-05910-1 